\title{
CONCEPTUALIZATION OF AXIOLOGICAL CONCEPTS IN UKRAINIAN FOLK SOCIAL FAIRY-TALES
}

\section{КОНЦЕПТУАЛІЗАЦІЯ АКСІОЛОГІЧНИХ ПОНЯТЬ \\ В УКРАЇНСЬКИХ НАРОДНИХ СОЦАЛЬНО-ПОБУТОВИХ КАЗКАХ}

\section{Pavlushenko Olha ${ }^{1}$}

DOI: https://doi.org/10.30525/978-9934-571-78-7_31

\begin{abstract}
The article contains a linguoculturological investigation of the conceptualization of axiological concepts of the «good» and the «bad» in the discourse of the Ukrainian folk social fairy-tale as a bearer of authentic national dispositions in the moral and ethical dimension and values orientations. These orientations are basic in the mankind's mental space in general, as well as in each individual ethnic community and in a certain person in particular. The goal of research was the comprehension of the conceptualization of axiological concepts of the «good» and the «bad» from the perspective of linguacultural studies in the discourse of the Ukrainian folk social fairy-tale as a bearer of authentic national dispositions in the moral and ethical dimension and values orientations, which are basic in the mankind's mental space in general, as well as in each individual ethnic community and in a certain person in particular. From the point of main research tasks, it is thought to fix all verbalisms of analyzing concepts for complete presentation of their meanings and to outline the set of additional features of words' senses, semantic connotations, associative, axiological and other parameters. For the research of axiological concepts in the language context of Ukrainian folk social fairy-tales it was used as the main a descriptive method, with the help of which it was presented the linguistic explicators of conceptual meaning. To determine the nominee field of the investigated concepts, we resorted to a contextual analysis. A method of component analysis helped to organize and structure the concepts' verbalizers. The field method promoted the construction of verbal models of the analyzed concept. A language and mental constructs, which are structured,
\end{abstract}

${ }^{1} \mathrm{PhD}$ in Philology, Associate Professor,

Associate Professor at the Department of Ukrainian Language,

Vinnytsia State Pedagogical University named by Mykhailo Kotsiubynsky, Ukraine 


\section{Chapter «Philological sciences»}

imply ambiguous analysis: the linguistic that reveals all the variety of verbal representatives of the same concept and the culturological, which is aimed to the study of linguistic signs in their relations with the material, social and spiritual nation culture. In an estimated thesaurus of Ukrainian fairy-tales we found 21 units of lectures and semantically undivided, predominantly phraseological phrase, paradigm-connected integrative sect «Positive estimation». In the discourse of Ukrainian folk social fairy-tale the axiological concept "bad" is verbalized by 24 lexical and phraseological units. In the analyzed language space segment, it was selected a core, near core zone and peripherals. Partly axiological characteristic hasn't a direct verbal exploit. Instead of that it appears through the fairy tale context, which adds expressive coloring of estimation of actions, signs, properties of persons, objects, etc. The context helps reception to set an estimation object and to determine the motives of positive or negative attitude to it. In Ukrainian folk social fairy-tales intelligence, hard work, courage, compassion, charity, courtesy dominates over cunningness, insidiousness, jealousy and laziness. The negative estimate of excessive wealth markedly dominates in the discourse of Ukrainian folk social fairy-tale. For the beliefs of Ukrainians this phenomenon causes unfeeling, envy, blunts the mind, prevents the joy of life, destroys family relationships between brothers, sisters, children and parents. Bread is the highest value of the Ukrainian husbandman. Working people don't exchange it for gold. Gold is of little value to them.

\section{1. Ветуп}

Сучасна лінгвістика виразно виявляє прямування в культурологічну та когнітивну площини досліджень. Оскільки концепти розкривають свою специфіку саме на перетині двох галузей - мови й культури, то цілком очевидно, що їхнє лінгвокультурологічне вивчення, $є$ найбільш актуальним і перспективним.

Все більше мовознавців схильні трактувати термін «концепт» як мовно-ментальну одиницю, яка $\epsilon$ носієм інформації не лише про базове поняття, а й про певний фрагмент світоглядної системи як всієї етноспільноти, так і кожного іiі члена. Формування лінгвокультурних концептів у мовно-ментальному просторі нації відбувається упродовж тисячоліть у безпосередньому зв'язку з історичними подіями, релігійними традиціями, міжна-родними відносинами, умовами природного середовища, господарською діяльністю й навіть побутовими звичаями. У свою чергу концепти культури чинять неабиякий вплив на 


\section{Pavlushenko Olha}

становлення окремої особистості, їі базових світоглядних переконань. Ці мовно-мисленнєві одиниці-конструкти, на відміну від понять, відображають соціальний та індивідуальний досвід представників певної лінгвокультури. Основу, ядро, цього досвіду найчастіше становлять архетипи, часто міфологеми, які представляють колективне несвідоме. А усвідомлений смисл концептів формують ті їхні сегменти, які містять сукупність всіх валентних зв'язків мовних, зокрема лексичних одиниць, позначених національно-культурною маркованістю у найширшому дискурсі, закоріненому в народній пісні, казці, легенді, міфі, фразео-логічному масиві - благодатному грунті мови фольклору $[5$, с. 6$]$.

Маючи членовану будову, мовно-ментальні конструкти припускають неодноплановий аналіз: власне мовний, який виявляє все розмаїття вербальних репрезентантів того чи того концепту, культурологічний, спрямований на дослідження мовних знаків у їхньому зв'язку 3 матеріальною, соціальною та духовною культурою нації.

Синтез мовних й культурних аспектів у дослідженнях концептів відкриває новий напрямок у сучасному мовознавстві, який уможливлює осмислення національної мовної картини світу у всій ії повноті, виявлення специфіки національного характеру, етнопсихології, світоглядних принципів, морально-етичних цінностей, розкриває всю самобутність етносу, його індивідуальні прикмети.

Дослідники одностайні в тому, що серед концептів культури виділяються базові, які становлять каркас національної мовної картини світу. Найбільш помітно такі мовно-ментальні одиниці проступають у фольклорному дискурсі у формі образів-символів. Їхню культурну значущість визначає ціннісний компонент, оскільки він акумулює аксіологічні домінанти, властиві колективній свідомості представників тієї чи тісї нації [4, с. 87]. Не можна не погодитися з тезою, що концепти відображають «дух народу», поєднують соціальність і «особисту сферу» носіїв етнічної свідомості $[1$, с. 8$]$.

Найдавнішим трансляційним каналом передачі від соціуму до окремої людини багатовимірних концептів культури були казки, які в наративній формі повідомляють наймолодшій генерації духовні орієнтири нації, притаманні їй морально-етичні еталони та ціннісні стереотипи. Казки не тільки знаряддя, а й продукт культури, тому є багатим джерелом для лінгвокультурологічного аналізу мови й дають змогу виділити автентичні цінності духовної царини етносу, виражені вербально. 


\section{Chapter «Philological sciences»}

Дискусійним залишається питання, які вербалізовані фрагменти поза-мовної дійсності можуть підлягати лінгвокультурологічному аналізові як такі, що містять духовне наповнення. Ми доєднуємося до кола тих дослідників, які вважають, що «більш виправданим видається широке розуміння завдань лінгвокультурології, яке передбачає концептуальне осмислення категорій культури в системі образів, що за своєю суттю $\epsilon$ місцем кумуляції світобачення народу» $[5$, с. 5]. Тому розглядаємо як духовно значущі не тільки концептуалізовані узагальнені абстрактні категорії добро, зло, справедливість, вірність, совість, воля, а й такі предметні, «опосередковані фольклором цінності» [5, с. 5], як, наприклад, хата, нива, мати, батько тощо. При цьому визначальним чинником опису імені концепту стає його контекстне оточення. Тільки аналіз відношень з іншими компонентами тексту, встановлення таких його характеристик, як процесуальність, предметність, означуваність уможливлює розуміння смислу певного мовно-ментального конструкту. В. Кононенко наголошує, що «для висвітлення смислу концепту потрібне залучення широкого набору додаткових щодо значення слова-поняття показників смислу, семантичних конотацій, асоціативних, аксіологічних та інших параметрів, які лише в своїй сукупності дозволять наблизитися до смислу концепту» [5, с. 15].

Тільки в народній казці можна віднайти найбільше таких концептів, які зберегли автентичні міфологічні конотації, первинні (язичницькі) й пізніші (пов'язані з християнством) релігійні асоціації, ритуальну чи обрядову функціональність. Дискурс фольклорної казки тяжіє до моделювання узагальнених образів, які абсолютизують національні цінності, концентрують глибинні засади автентично-ментального, виступають носіями концептуальної картини світу в їі первісному вияві.

У пропонованій розвідці маємо на меті осмислити з позицій лінгвокультурології концептуалізацію аксіологічних понять добре, погано в дискурсі української народної соціально-побутової казки як носія автентичних настанов нації в морально-етичній площині й виразника ціннісних орієнтирів, які виступають засадничими в ментальному просторі людства в цілому, кожної окремої етноспільноти й конкретної особистості зокрема. Колом дослідницьких завдань передбачено зафіксувати всі вербалізатори аналізованих концептів, для повного висвітлення їхніх смислів окреслити набір додаткових щодо значення слів-понять показників смислу, семантичних конотацій, асоціативних, аксіологічних та інших параметрів. 


\section{Pavlushenko Olha}

Методологія дослідження. Для дослідження аксіологічних концептів у мовному просторі фольклорних українських казок як основний використано описовий метод, за допомогою якого представлено мовні експлікатори концептуального змісту. Щоб визначити номінативне поле досліджуваних концептів, ми вдалися до контекстного аналізу. Метод компонентного аналізу допоміг впорядкувати вербалізатори концептів, польовий метод сприяв побудові словесних моделей аналізованих концептів.

\section{2. Аксіологічне поняття добре у філософській традиції}

У філософській думці аксіологічні поняття добре й погано трансформувалися в категорії етики й моральної свідомості добро й зло, які в загальній формі відображають розмежування морального й аморального, схвального й осудного соціумом, прийнятного й неприйнятного в мотивації діяльності, вчинків, особистісних якостях окремої людини й соціальних явищах в цілому. Цілком очевидною є залежність оцінок добре / погано від соціокультурного контексту, світоглядного досвіду. Концептуалізація аналізованих аксіологічних понять відбувається через призму встановлення норм поведінки й вчинків індивіда в родинній й суспільній спільноті. Загальнолюдське схвалення й оцінку добре одержали чесноти, які визнані як моральні цінності: мудрість, мужність, справедливість, поміркованість, невибагливість, смиренність, доброчинність, співчуття до ближнього.

Мовно-ментальний конструкт добро у філософському трактуванні це «найзагальніше оцінне поняття, яке відображає позитивний аспект людської діяльності» [9, с. 124]. Це система моральних засад як поведінки в цілому, так і окремих вчинків конкретного індивіда й усього суспільства, які колективна свідомість схвалює і розглядає як такі, що спрямовані на благо й удосконалення світу людей. Традицією, що бере свій початок ще в античності, склалася думка, що в основі моральності лежить прагнення до доброго.

\section{3. Вербалізація позитивної оцінки в українській лінгвокультурі}

Осмислення й опис концептуалізації одних з основних аксіологічних категорій добре /погано в контексті народної казки, яка найкраще відображає світоглядні прикмети українців, сприятиме реконструю- 


\section{Chapter «Philological sciences»}

ванню цілісного етноментального, етнопсихологічного й етномовного простору нації.

Лексичним вираженням позитивної оцінки в українській мові слугує прислівник, добре, який перебуває у відношеннях дериваційної мотивації з якісним прикметником добрий. Слово добрий має той самий первісний корінь, що й праслов'янський прикметник dóba, який означав «відповідний, корисний, той, що підходить» [2, с. 98]. Словник сучасної української мови слово добрий тлумачить так:

1) який доброзичливо, приязно, чуйно ставиться до людей; доброзичливий; протилежне лихий, поганий;

2)привітний, лагідний у взаєминах;

3) який виражає доброту, щирість; сповнений ласки, приязні (про голос, усмішку, обличчя ін.);

4) для якого характерна взаємна прихильність, симпатія, близький;

5) який приносить добро, задоволення, радість;

6) корисний, потрібний, в основі якого лежить бажання добра кому-небудь;

7) який подобається, схвалюється, вартий наслідування;

8) у знач. ім. до́бре, -рого, с. р. те саме, що добро́;

9) який свідчить про безтурботний, веселий стан людини;

10) який має належні знання і навики для виконання чого-небудь, досвідчений;

11) який користується повагою, шаною;

12) розумно вихований, увічливий, працьовитий;

13) який має позитивні якості або властивості, що відповідають поставленим вимогам, задовольняють їх (про предмети, тварини, рослини);

14) вигідний, зручний для роботи, влаштування яких-небудь справ, заробітку;

15) значний щодо розміру, обсягу, кількості;

16) кращий від звичайного, багатий, великий, високий;

17) який повністю забезпечує потребу в чому-небудь;

18) гідний шани, похвали; незаплямований [7, с. 321].

Осмислення й опис концептуалізації одних з основних аксіологічних категорій добре /погано в контексті народної казки, яка найкраще відображає світоглядні прикмети українців, сприятиме реконструюванню цілісного етноментального, етнопсихологічного й етномовного простору нації. 


\section{Pavlushenko Olha}

В оцінному тезаурусі українських казок нами виявлено 21 одиницю лексем й семантично неподільних, переважно фразеологізованих, словосполук, парадигматично пов'язаних інтегративною семою «позитивна оцінка»: добрий, гарний, красний, милий изіний, добре, хорошо, щуасливо, все в порядку, як по маслу, до діла, до пуття, слава Богу, душа радується, красне діло, добре слово, чудо, матися в гараздi, нічого собi, порядок навести, гаразд. Можемо обгрунтовано стверджувати, що лексеми добрий, красний, гарний, добре, хорошо, щасливо за частотністю вживання в аналізованому сегменті мовного простору належать до ядрової зони лексико-семантичного поля вербалізаторів досліджуваного концепту (у межах від 15 до 20 слововживань на 60 опрацьованих текстів), до приядрової зони, за нашими спостереженнями, потрапляють фразеологізовані вирази: прекрасний, все в порядку, як по маслу, до діла, до пуття, у великій пригоді стати, слава Богу, душа радується, добре слово, чудо (5-9 фіксацій), на периферії мовно-ментального конструкту добре перебувають красне діло, матися в гараздi, нічого собi, порядок навести, гаразд (у значенні прислівника добре).

- Ой, як добре! Я жив би тут, коли б ия дівчина хотіла за мене віддатися (Брати-сироти і батьківська порада) [11, с. 116].

Скаже, слава богу, що хоч живий вернувся (Калиточка) [11, с. 28].

Хлопецьь відповів:

- Все в порядку (Казка про майстра Іванка) [11, с. 87].

- Дівчина дуже зраділа і пішла з Іванком у далекі краї. Там вони побралися та щасливо живуть... (Там само).

- Ну, хорошо, щчо тепло (Москаль у пеклі) [11, с. 92].

- Красне діло, каже середущий, - айбо я щзе изінніше купив. Я дiстав такий плащ, шо як розпростерти і на нього сісти, понесе тебе, куди лише задумаєш (Про найцінніше) [11, с. 103].

- Хто не хоче гаразд честувати, той біди зазнає (Ситий голодному не вірить) [11, с. 97].

- Нехай вона вам до пуття розкаже, коли $і$ як те було (Язиката Хвеська) [11, с. 165].

- Жили хлопиі самі. ... слова батька пам'ятали. Малися в гаразді (Брати-сироти і батьківська порада) [11, с. 114].

- Як сядуть їсти, то серие болить, а як стануть робить, то дуиа paдусться! (Про бідного парубка і Марка Багатого) [11, с. 180]. 
- Йди лище сюди! - покликав середущуого. Видиш, які прекрасні дівчата? (Про найцінніше) [11, с. 104].

Лексеми добре, добрий, милий, иінний, що становлять ядро концепту добре у вербальному просторі української народної казки, представлені граматичними формами, які виражають різні ступені інтенсивності позитивної якості чи властивості реалії, дії, вчинку: лучче (діалект.), ліпше, найліпме, краще, найкраще, наймиліме, найцінніме.

- Я одна, а вас троє. За того віддамся, котрий за рік принесе найцінніме. (Про найцінніше) [11, с. 104].

- Це ше й краще, буде у нас молоко (Калиточка) [11, с. 29].

Та й пішов собі дальше, лучче шукати (Москаль у пеклі) [11, с. 92].

- Ідім по світу! Будемо глядати ліпше життя (Брати-сироти і батьківська порада) [11, с. 115].

На базі словотвірної основи прикметника добрий утворився іменник добро на позначення поняття майно, який отримав надзвичайно широке використання в народній мовленнєвій практиці, заступивши собою узусну номінативну одиницю майно:

Поклали слуги на віз багато добра ... (Яка любов найліпша?) [11, с. 157]

Синтагматичні зв'язки лексичних та фразеологічних одиниць, зафіксованих у текстах народних казок, вербалізують в структурі досліджуваного мовно-ментального конструкту концептуальні аспекти, які суспільна свідомість української спільноти витворила в результаті довготривалої мовленнєвої практики та життєвого досвіду. Виокремимо найбільш помітні з них, послуговуючись принципом нисхідної ієрархії за частотністю.

Оцінкою добре українці здавна відзначали достаток, добробут, безбідне, проте без зайвих розкошів, життя, якого людина досягає своєю наполегливою працею чи заслуговує героїчними вчинками:

Оженився молодюк, почав газдувати. Побудував собі хатину, посадив садок. Народилося в сім ї двоє діточок - дівчика і хлопчик. Жилося людям добре (Життя і смерть). Жили-були два брати - Петро та Іван. Петро жив добре. Мав гарну хату, i в хаті, й коло хати (Дарунки груші) [11, с. 164].

І жилося відтоді Василеві з родиною добре (Брати-сироти і батьківська порада) [11, с. 115].

Добре, за думкою багатьох поколінь українців, виявляти сумління у виконанні своїх обов'язків й працьовитість. За ці якості персонажі соціально-побутових казок повсякчас отримують достойну винагороду: 


\section{Pavlushenko Olha}

- Чекай, я тобі за добру службу мушу віддячитися (Яка любов найліпша?) [11, с. 157]. Брати повставали з-за столу, закасали рукави поза лікті й узялися до роботи. Добре потрудилися ... (Закопане золото) $[11$, с. 180$]$.

Здавна українці високо цінували корисну пораду і були переконані, що це найкраща послуга:

- Ні, ти мною не наїсися, чоловіче, краще пусти мене, $i$ я тебе навчу трьох речей, які тобі у великій пригоді стануть. Той чоловік втішився і пообіияв відпустити, якщяо той добре скаже (Як соловейко чоловіка розуму навчив) [11, с. 190].

Традиційно під поняття добре в суспільній свідомості українського народу підпадає досконалість, достатність, високий гатунок:

А тютюн добрячий, мічний... . ...бо табака була добре заправлена... (Козаки і смерть) [11, с. 197].

... да уродило таке хороше просо, таке хороше! (Семиліточка) [11, c. 192].

Довго блукав парубок по чужій стороні, розвідав ї̈ добре (Про бідного парубка і Марка Багатого) [11, с. 237].

Їде та їде, коли дивиться - аж біжить собака і несе намисто добре, товсте та гарне, та ще й шліфоване (Дідова дочка й бабина дочка) [11, с. 128].

А груша росла собі, кожний рік врожай добрий давала.

- Це чудо, а не груші. Таких груш у світі нема. А тут пани приїхали груші куплять. Гарні гроші дають за груші (Чудо-груша) [11, с. 189].

Лексемами добре, добрий український народ, зазвичай, виражав вдячність, повагу особі, яка своїми діями й вчинками заслужила цього, і в мовленнєвій практиці вживав ці прикметники як компоненти пошанівних звертань:

Добрий мій хазяїне, спасибі тобі за все, за ласку, за те, щэо ти жалієш мене (Чудо-груша) [11, с. 189].

Оскільки достатнє, проте не надмірне майнове забезпечення людини й родини в системі аксіологічних координат українського народу перебуває на осі добре, то мовна практика утворила від основи прикметника добрий номінатив добро, який послідовно витіснив іменник майно чи словосполуку матеріальні иінності:

А сама наготувала повнісіньку скриню всякого добра, дала їй $і$ випровадила з лісу (Дідова дочка й бабина дочка) [11, с. 128]. 
Idimb, maту, забирайте добро! (Там само)

I наклав аж п'ять возів усілякого добра: калачів, меду, яєщь, шовку (Бідний гуцул і старий опришок) [11, с. 146].

У відношеннях словотворчої мотивації з прикметником добрий перебуває іменник добрість, який в українській мові виступає синонімом до слова прихільність і виражає добре ставлення до когось. Узвичаєним стало вживання цього слова у фразеологізованому виразі знай мою добрість:

- Нюхай, - каже, - та знай мою добрість (Козаки і смерть) [11, c. 197].

Позначення словом добре позитивної оцінки зумовило вживання його в мовленнєвій практиці у значенні згоди:

- Добре, паніматко, так буду робити, як ви мене навчили (Дідова дочка і бабина дочка) [11, с. 129].

\section{4. Аксіологічне поняття погано у філософськом осмисленні}

В аксіологічній площині мовної картини світу поняттю добре протиставляють поняття погано. Філософія розглядає аксіологічне поняття погано як зло - категорію, що охоплює усе ціннісно-негативне, протилежне щодо блага й добра. Зло підриває продуктивні потенції суспільства, руйнує умови й засоби фізичного і духовного розвитку людини. Особливе місце посідає моральне зло, серед різновидів якого виокремлюють дві переважні форми - ворожість і розбещеність. Перша пов'язана з агресивністю і жорстокістю. Друга - з девіантними нахилами. Загалом - це прагнення утвердити власне часткове існування за рахунок інших і на шкоду іншим [10, с. 227].

До поширених виявів зла в загальнолюдському розумінні відносять різноманітні форми деструктивності й девіації: ворожість в думках і діях до людини, корисливе ставлення до неї як до знаряддя одержання вѝгоди, гріховне з позицій релігійної етики, невігластво - все, що в суспільній свідомості позначено оцінкою «погано».

\section{5. Вербалізація негативної оцінки в українській лінгвокультурі}

Прислівник погано на українському лінгвальному грунті є дериватом від прикметника поганий з псл. qапа «образа» [4, с. 473].

Словник сучасної української мови так тлумачить значення слова поганий: 


\section{Pavlushenko Olha}

1) який не має добрих якостей, властивостей; не такий, як треба, викликає негативну оцінку;

2) неприємний своїми якостями, властивостями (несмачний, смердючий і т. ін.);

3) некорисний або шкідливий;

4) несприятливий, похмурий (про погоду, день і т. ін.);

5) який не задовольняє поставлених вимог, не відповідає цим вимогам, певним потребам;

6) виконаний недосконало, немайстерно, невправний;

7) недосвідчений, невмілий (про людину);

8) не відповідає звичайним нормам, відхиляється від нормального (про стан, відчуття, життєві функції організму і т. ін.);

9) нездоровий, хворий (про органи тіла, організм);

10) який не обіцяє нічого доброго, віщує лихо, небезпеку або неприємність;

11) невтішний, сумний;

12) невеселий, гнітючий;

13) поганий настрій;

14) нещасливий, важкий, жорстокий;

15) те, що віщує лихо, небезпеку або неприємність;

16) якому властиві негативні моральні якості (про людину);

17) недоброзичливий, неприязний, злий;

18) вартий осуду (про манери, поведінку, вчинки і т. ін.);

19) який ганьбить, плямує кого-небудь;

20) грубий, брутальний, непристойний [8, с. 701].

У дискурсі народної соціально-побутової казки аксіологічний концепт погано вербалізується такими лексичними та фразеологічними одиницями: поганий, погано, погане (субстантив), не годиться, неподобний, зле, лихо, злиденне, убоге, нікчемне, дивитись гидко, сто чортів з таким (такою) ...., біда, лихо спіткало, сяка-така, лукавий попутав, бісів син, паскудство, бісів батько, лиха година, не знав, як із злиднів вийти, злує, місия собі не знаходить, страшний (всього 24 одинииі).

Ядро лексико-семантичної групи експлікаторів негативної оцінки становлять слова поганий, погано, погане (субстантивований прикметник), зле, лихо, біда, страшний. Приядрову зону формують слова й вирази: убоге, не годиться, неподобний, нікчемний, дивитися гидко, паскудство, лукавий попутав (погано вчинив), лиха година (поганий 


\section{Chapter «Philological sciences»}

час, поганий збіг обставин), бісів син / бісів батько (зневажливе ставлення до людини, яка заслужила його своєю поганою поведінкою чи нікчемним вчинком), місия собі не знаходить (погано почувається). Периферійними вербальними засобами аналізованої мовно-ментальної одиниці виступають: лихо спіткало, сяка-така (не дуже добра), злує (погано ставиться), сто чортів з таким (такою) ... (вираження низької оцінки). Вищий ступінь інтенсивності негативної якості чи властивості реалії, дії, вчинку виражає граматична форма гірше.

В основі концептуалізації поняття погано в дискурсі української народної казки лежать переважно аспекти, пов'язані з негативною оцінкою девіантної поведінки людей. Суспільному осуду українці здавна піддавали лінощі. 3 персонажами казок, які намагаються уникати праці, трапляються пригоди, що переконують їх змінити своє ставлення до роботи: ... увійшов чоловік у хату та й сам собі не вірить:

- Що иее з тобою, жінко, сталося?

- E, мовчи, чоловіче, - відказала Явдоха. - Бач, Бог довідався, щчо я нічого не роблю, та прислав Івана Хрестителя, а той як зачав мене хрестити, то ледве живу пустив.

Од того дня Явдоха такою хазяйкою зробилася невсипущью - на все село (Явдоха-святоха) [11, с. 125].

Засуджував український народ вияви зверхності та зневаги у ставленні до співгромадян. Цілісні сюжетні рамки казок «Баба і гладущик молока», «Вчений вовк» виражають негативне оцінювання таких вчинків:

Запряжу я тії биченята до возика та й буду їхати на ярмарок; а як хто буде мене просити: «Бабко-серие, підвезіть!», то я ногою т-тур. Баба спересоння сунула ногою в гладущчик; гладущик полетів з запічка на землю і розбився в куски, а молочко покотилося білою річкою по чорній землі (Баба і гладущик) [11, с. 233]. Так того чоловіка ия груба річ за серие й узяла, як крикне ж він на генерала:

- А у ярмо $i$ забув? (Вчений вовк) [11, с. 243]

3 позицій народної моралі в українців не годилося забувати про добру послугу, пораду, допомогу в скруті. У соціально-побутовій казці той, хто чинить всупереч цій суспільній нормі, обов'язково має бути покараний, проте кара ніколи не буває фізичною, а пов'язана з втратою майна:

Тоді чудотвореиь каже:

- Зніміть свої постоли та закопайте їх у землю .... Та буде у вас все. 


\section{Pavlushenko Olha}

Через три роки прийшов чудотворецьв у те село. «Ану, - думає, зайду до сього газди, чи пустить переночувати»

Зайтов, звідує:

- Чи не переночував би я у вас?

- Нi, бо ви можете мені хату запаскудити.

Той щее дочікувався, а газда спустив пса. То було восени, все уже звезли з поля.

Каже чудотвореиь:

- Як тобі прийшло, най так і піде!

I обійстя спалахнуло (Ситий голодному не вірить) [11, с. 98].

Суспільному осуду українці піддавали надмірну говірливість:

Нема гірше од того чоловіка, що не вміс язика за зубами вдержати ! А найбільше лихо з жінками; ... від Хвеськи не сховаєшся, вона по всьому селу рознесе. Що його робити? «Треба, - каже, - одучити жінку від такої поганої звички». - Не я тебе підвів, ти сама себе підвела! От не ляпай ніколи по-дурному язиком, то нічого й не буде. А Хвеська бачить, щзо лихо багато балака, та й знишкла. (Язиката Хвеська) [11, с. 167].

Здавна український народ негативно оцінював зажерливість, прагнення до необмежених статків, скупість. Красномовною у цьому плані $\epsilon$ казка «Про бідного багача». Розповідь про чоловіка, якому дивним чином дістався чарівний гаманець, що зробив свого власника багатим, переконливо резюмує:

Так і умер з гаманцем у руках серед великих куп золота. Hi собі, ні другим людям добра не зробив. Золото засліплює людей, робить їх зажерливими і нещзасними. (Про бідного багача) [11, с. 223].

Негативна оцінка поведінки персонажа виражена предикатами умер, не зробив добра, засліплює, робить нещасними. Це попередження про те, що жадоба до надмірного багатства є не тільки соціально шкідливим явищем, а й несе індивідуальну небезпеку тому, хто страждає цією схильністю. Це ж у розмові з юнаком стверджує старий умудрений життям пастух у казці «Срібні воли»:

- Дідуню, коли я оборював поле, то бачив людей. Один лежав біля хліба і просив хліба, другий - біля води і просив води, третій - біля вогню $і$ було йому холодно, а четвертий мав гору грошей і просив грошей.

- То все пани, синку, ... перший мав гори хліба, але, коли бідні голодували, він нікому ніколи не давав. Другий жалів навіть води, коли на його полі праџювали в спеку. Той, щуо біля вогню лежав $і$ було йому 


\section{Chapter «Philological sciences»}

холодно, мав свій ліс, але він убивав людей, якщо якогось спіймав із в',язкою в своєму лісі. То дивися у тебе буде всього досить, але якщо хтось до тебе зайде $і$ чогось попросить, то аби ти ніколи не шкодував дати (Срібні воли) [11, с. 222].

Почасти аксіологічна характеристика немає прямої вербальної експлікації, а проступає крізь контекст казки, який додає експресивного забарвлення оцінці дій, прикмет, властивостей осіб, предметів тощо. Метою оповіді $є$ підвести читача до висновку про високу чи низьку оцінку поведінки персонажа. Наратор безпосередньо не оцінює вчинки персонажів. Контекст допомагає реципієнтові встановити об'єкт оцінювання, визначити мотиви позитивного чи негативного ставлення до нього. Читачі (переважно діти) мають зробити це самі, що потребує від них певних інтелектуальних зусиль, набуває характеру пізнавального процесу. Для прикладів звернемося до казок «Брати-сироти і батьківська порада», «Закопане золото», «Кирик», «Чому море солоне», «Як Іван когутів ділив», «Хліб і золото», «Про старого неня», «Семиліточка», «Про бідного парубка i Марка багатого», «Козаки і смерть», «Як бідняк чорта обдурив» та ін. Предметами оцінювання у цих казках виступають переважно вчинки персонажів, які представляють різні майнові стани соціуму. У багатьох казках в антагоністичні стосунки вступають рідні брати.

Конфлікт між багатим і бідним часто виходить за межі майнової нерів-ності й набуває конотацій змагання честі з безчестям, справедливості з несправедливістю, верховенства права власників багатсв над безправ’ям убогих («Казка про майстра Іванка», «Два брати», «Чудогруша», «Про бідного і багатого брата», «Дарунки груші», «Яка любов найліпша?»).

Благородство й альтруїзм керують вчинками героя «Казки про майстра Іванка» і протиставляють простого хлопця, сумлінного й доброго, бездушному цареві. Майстер Іванко, бідняцький син, вирушає на пошуки щастя і вже на початку своєї подорожі має нагоду виявити благодійництво - на останні три крейцари «справив похорони» незнайомого чоловіка. Пізніше, успішно виконавши завдання царя, одержує від нього обіцяну винагороду - три вози золота, проте відмовляється від заробленого, його вибір інший:

- Не треба мені золота, ані вашого маєтку, лиш дайте мені те, щзо сидить у мурі. І ияар випустив з муру дівчину. Дівчина дуже зраділа і пішла з Іванком у далекі краї. Там вони побралися та щзасливо живуть $і$ нині. 


\section{Pavlushenko Olha}

Таке закічення казки підводить до висновку: у системі цінностей українців сімейне щастя і родинний затишок $\epsilon$ найвищою винагородою за благородні вчинки, а за світоглядними традиціями української спільноти, великодушність та благодійництво $\epsilon$ найкращими якостями людини, які заслуговують на найвищу оцінку.

Сюжетна рамка казки «Хліб і золото» красномовно переконує, що в системі ціннісних координат українців хліб займає вищу позицію, ніж золото:

Не стало в пана хліба. Як не шкодував, а взяв кусень золота і поніс до бідняка, щуоб поміняти на хліб. Бідняк не взяв золота, але відрізав половину хлібини панові, половину залишив собі. 3 окрайця у бідняка виросла нова хлібина. 3 окрайия у пана хлібина не виросла... (Хліб і золото) [11, с. 191].

У світоглядних традиціях українців як хліборобської нації закарбувалося одвічне шанування землі-годувальниці і праці землероба-сіяча. Саме цю концептуальну ідею містить висновкова частина казки «Закопане золото»:

Пішли ниву копати. Скопали ниву - нема золота, але посіяли яру пшеницю - вродилася пшениця така буйна, така здорова! Помолотили, відвезли зерно до млина, намолотили муки, напекли хліба, посідали свій хліб їсти, а наймолодший брат говорить:

- Ой, які ми брати, дурні! Бачите? Золото уродилося. Добре нам тато казав, аби ми шукали в землі золото!

Брати повставали з-за столу, закасали рукави поза лікті й узялися до роботи. Відтоді земля давала їм золото: родився хліб. (Закопане золото) [11, с. 231].

В етноментальності українців споконвіку закладено повагу до винахідливості, кмітливості, розуму, мудрості. Вияви неабиякого інтелектуального потенціалу в народних казках традиційно пов'язуються 3 подоланням героєм (селянином, бідняцьким сином чи дочкою) певних труднощів, виконанням складних завдань і врешті перемогою над багатими, проте нерозумними панами чи царями. Натомість розумова недолугість, інтелектуальне убозтво у світоглядних традиціях української нації завжди піддавалися осуду, висміювалися. Показовою у цьому плані $\epsilon$ казка «Семиліточка». Селянська дочка успішно опонує панам і доводить свою перевагу простими і переконливими аргументами:

От так пан вже побачив, щуо вона розумніша, дав їй півпанства, да стала вона вже у нього розсуджувать людей; ото пан такий був, що не розсудить і людей. (Семиліточка) [11, с. 186]. 


\section{Chapter «Philological sciences»}

Кмітливість рятує козаків від смерті в казці «Козаки і смерть». Смерть відступає, обдурена вигадливими молодцями. У казці «Як бідняк чорта об-дурив» розумову силу бідняк протиставляє фізичним перевагам чорта й перемагає його та ще й одержує від нечистивця мішок золота. Перехитрив наймит чортів і в казці «Дурні чорти та хитрий наймит».

Не тільки розум, а й відвага селянських дітей, сиріт була помічена на-родом і належно оцінена. Цікавим є сюжет казки «Про бідного парубка і Марка багатого». Юнак діє рішучо і сміливо, не вагається у небезпечних ситуаціях. Підступний намір багатого Марка знищити свого похресника - бідняцького сина повертається для зловмисника довічним ув'язненням на зачарованому плоту, а «парубок роздав усе його багатство бідним, і стали бідні жити-поживати та добра наживати». (Про бідного парубка і Марка багатого.) [11, с. 181].

Традиційним для народних казок є сюжет, який грунтується на протиставленні нерідних сестер. Дідову дочку, зазвичай, наділено найкращими якостями: працьовита, чемна, невибаглива, скромна. Антиподом виступає бабина дочка як носій негативних, за національною аксіологічною шкалою, ознак: ледача, невміла, зарозуміла й зверхня в стосунках 3 людьми, неохайна, вередлива. Бабина дочка одержує майнову винагороду та суспільне схвалення, а дідова дочка моральне покарання.

Фольклорні казки є правдивим джерелом інформації про світоглядні орієнтири нації. У них сам народ розповідає про себе, своє розуміння, що $\epsilon$, за його думкою, добре, а що погано. Аналіз дискурсу народної казки дозволяє з найбільшою достовірністю скласти уявлення про концептуалізацію аксіологічної системи нації.

\section{6. Висновки}

Світоглядні горизонти українців сягають глибокої праслов'янської давності. Тоді ж, за свідченнями багатьох авторитетних дослідників [6], почала формуватися українська мова, яка відобразила і пронесла через віки філософію життя українського етносу, його духовні набутки, світоглядний досвід, сформований у результаті спостережень за природою, яка оточує, і природою самої людини, тих суспільних формацій, які вона створювала упродовж тисячоліть.

Еволюційна історія українців складна, позначена постійною боротьбою за національне й культурне виживання. Оглянімося в минуле і не 


\section{Pavlushenko Olha}

побачимо жодного століття, щонайменшого відтинку часу, упродовж якого Україна могла б розвиватися вільно, не зазнаючи ідеологічної, культурної, мовної експансії чужинців. Проте, незважаючи на агресивний наступ окупантів різних мастей на національну самобутність, українці зберегли людинолюбство, толерантність, схильність до добродійності. Гуманістичні ідеї становлять філософську основу концептуалізації аксіологічних максим добре й погано в народному трактуванні. Вічно живим свідченням цього залишаються фольклорні твори. В українських соціально-побутових казках за суспільно усвідомленими ціннісними критеріями розум, працьовитість, відвага, чуйність, доброчинність, чемність має безсумнівну перевагу над хитрощами, підступністю, заздрощами, лінощами. Найціннішими винагородами позитивним персонажам за їхнє сумління й відвагу є родинний затищок у любові, злагоді, скромному, але достатньому для задоволення життєвих потреб майновому забезпеченні. Це те, що не підлягає заміні на царства, чужі землі, коштовності. У дискурсі української народної казки помітно домінує негативна оцінка надмірного багатства, яке, за переконанням українців, породжує бездушність, заздрість, притуплює розум, заважає відчувати радість життя, руйнує родинні стосунки між братами, сестрами, дітьми й батьками. За найвищу цінність українціхлібороби мають хліб. Люди праці не обмінюють його на золото, яке для них меншовартісне.

Подальші дослідження народної казки та інших фольклорних матеріалів виявлять особливості автентичної лінгвокультурної царини українців, допоможуть зрозуміти ті чи ті рефлексії сучасного українського соціуму на виклики сьогодення, розкриють базові уявлення, що визначають світоглядні орієнтири нації на майбутнє.

\section{Список літератури:}

1. Воркачев С.Г. Концепт как зонтиковый термин [в]. Язык, сознание, коммуникаиия. Москва, 2003. Вып. 24. С. 8.

2. Етимологічний словник української мови. У семи томах. Том 2. / Укладачі: О.С. Мельничук (головний редактор), В.Т. Коломієць, О.Б. Ткаченко. Київ, 1985. С. 98.

3. Етимологічний словник української мови. У семи томах. Том 4 / Укладачі: О.С. Мельничук (головний редактор), В.Т. Коломієць, О.Б. Ткаченко. Київ, 2003. С. 473.

4. Карасик В.И. Языковой круг: личность, концепты, дискурс. Волгоград, 2002. C. 87. 


\section{Chapter «Philological sciences»}

5. Кононенко В.І. Концепти українського дискурсу. Монографія. Київ Івано-Франківськ, 2004. С. 5, 6, 15.

6. Півторак Г.П. Походження українців, росіян, білорусів та їхніх мов. Міфи і правда про трьох братів слов'янських зі «спільної колиски» Київ, 2001. 346 с.

7. Словник української мови. В 11 томах. Том 2 / Ред. І.К. Білодід. Київ, 1970-1980. С. 321.

8. Словник української мови. В 11 томах. Том 6 / Ред. І.К. Білодід. Київ, 1970-1980. С. 701.

9. Философский словарь / Ред. И.Т. Фролов, 6 изд. Москва, 1991. С. 124.

10.Філософський енциклопедичний словник. Київ, 2002. С. 227.

11.Золота книга казок. Українські народні казки. Київ, 1990. 430 с.

\section{References:}

1. Vorkachev S.H. Kontsept kak zontykovyi termin [v]. Yazyk, soznanye, kommunykatsyia. Vyp. 24. Moskva, 2003. S.8.

2. Etymolohichnyi slovnyk ukrainskoi movy. U semy tomakh. Tom 2 / Ukladachi: O.S. Melnychuk (holovnyi redaktor), V.T. Kolomiiets, O.B. Tkachenko. Kyiv, 1985. S. 98.

3. Etymolohichnyi slovnyk ukrainskoi movy. U semy tomakh. Tom 4 / Ukladachi: O.S. Melnychuk (holovnyi redaktor), V.T. Kolomiiets, O.B. Tkachenko. Kyiv, 2003. S. 473.

4. Krasyk V.Y. Yazykovoi kruh: lychnost, kontseptы, dyskurs. Volhohrad, 2002. S. 87.

5. Kononenko V.I. Kontsepty ukrainskoho dyskursu. Monohrafiia. Kyiv Ivano-Frankivsk, 2004. S. 5, 6, 15.

6. Pivtorak H.P. Pokhodzhennia ukraintsiv, rosiian, bilorusiv ta yikhnikh mov. Mify i pravda pro trokh brativ slov'ianskykh zi «spilnoi kolysky» Kyiv, 2001. 346 s.

7. Slovnyk ukrainskoi movy. V 11 tomakh. Tom 2 / Red. I.K. Bilodid. Kyyiv, 1970-1980. S. 321.

8. Slovnyk ukrainskoi movy. V 11 tomakh. Tom 6 / Red. I.K. Bilodid. Kyiv, 1970-1980. S. 701.

9. Fylosofskyi slovar / Red. Y.T. Frolov, 6 yzd. Moskva, 1991. S. 124.

10. Filosofskyi entsyklopedychnyi slovnyk. Kyiv, 2002. S. 227.

11. Zolota knyha kazok. Ukrainski narodni kazky. Kyiv, 1990. 430 s. 